\title{
Väderkontraktet: plats, miljörättvisa och eskatologi i Astrid Lindgrens Vi på Saltkråkan
}

http://urn.kb.se/resolve?urn= urn:nbn:se:sbi-22

Abstract:Astrid Lindgren's children'snovel Vi påSaltkråkan(1964) which is set in the outer archipelago of Stockholm is an ideal case for the study of a variety of eco-or "environmental critical" (Buell, 2005) themes and motifs. There is for instance, the ideo-historical motif of the representation of a number of positions on nature and the physical environment generally, from the most anthropocentric one of Vesterman over the "sociocentric" (Buell 2005) view represented by the Grankvist family, to the eco- or biocentric stand of Pelle, which is epitomized in his love and defense of all kinds of animals including the most threatening and irritating ones. There is also the ecocritical generic problem of the idyll. More themes could be named. What will be at the centre of attention in this article, however, is the motif of weather as connected to that of locale, or place, and the Melkersons and the islanders' defense of place. I suggest that part of the novel's environmental relevance lies in what could be understood through the metaphor of contract: the characters enter a contract of dependence through the category of weather. This contract is deeply place-related and existentially loaded. The motif of weather cuts into the idea of environmental justice (Adamson, Evans and Stein, 2002), through the Melkersons' struggle to save Snickargarden, a struggle which is shared by the islanders themselves. The weather always serves to underscore the Melkersons' attachment to place which is one of deepest solidarity, and to home. The novel contains an escathological undercurrent related to place and to weather. In the emphasis on this, the novel offers a profound environmental insight into the dependence of human existence upon environment.

Keywords: ecocriticism, environmental criticism, Astrid Lindgren, $V i$ på Saltkråkan, environment, nature, landscape, place, weather, eschatology, environmental justice. 
Liksom i många av Astrid Lindgrens berättelser, i synnerhet de idylliska, är naturen påtagligt närvarande i romanen Vi på Saltkråkan (1964). Men till skillnad från dem uppvisar Vi på Saltkråkan en mångfald motiv som på ett slående sätt kan analyseras med hjälp av den relativt nya litteraturkritiska praktiken eko- och miljökritik (ecocriticism, environmental criticism). Än viktigare är, att det jag vill föreslå som en eskatologisk underström kopplad till romanens miljökritiska nivå, vilken definieras av motiv som rör naturmiljö, plats och social gemenskap, skär rätt in i några av de allra senaste riktningarna inom eko- och miljökritiken. Tre av dessa är frågan om klimatet och extrema väderfenomen; djurstudier eller zookritik; samt den allt viktigare frågan om miljörättvisa (environmental justice). Generellt kan man säga att den sista frågan har åstadkommit en förändring i forskningsemfas inom ekokritiken. Från att man inom ekokritisk forskning tidigare huvudsakligen har fokuserat genrer som naturlyrik och naturberättande (naturewriting) där tonvikten ofta legat på naturen "som sådan" och skild från det mänskliga, betonas i dag snarare den mera komplexa frågan om hur hotade fysiska miljöer - det vill säga naturmiljön, den byggda miljön och invånarna som del av dessa miljöer - tillsammans skildras i litteraturen och andra kulturella genrer (Buell 2005, 17-28). Förändringen avspeglas också i disciplinens namn, som har utvecklats från vad Lawrence Buell benämner en "första vågens ekokritik" till "andra vågens miljökritik" (ibid, 17; jfr. Heise, 2008, 13). Termen ekokritik har för den skull inte blivit obsolet. Den varierade terminologin avspeglar dels en historisk förändring inom själva disciplinen, men också en intellektuell problematisering, teoretisering och en tydligare distinktion mellan de studerade företeelserna. I den här artikeln används båda termerna, ibland skilt för sig beroende på vilket fenomen som omtalas, och ibland gemensamt då företeelserna är relaterade till varandra eller ingen tydlig skillnad finns. Tonvikten ligger dock på termen miljökritik. Innan en diskussion av väder, plats och eskatologi vidtar, kartläggs emellertid det överflöd av motiv som erbjuder sig för eko- och miljökritiska läsningar av Vi på Saltkråkan och som samtidigt, förhoppningsvis, väcker intresse för nyläsningar av delar av Astrid Lindgrens författarskap i dylika termer

\section{Spektret av positioner och miljömotiv}

I sina två böcker Astrid Lindgren: a critical study (Edström, 2000) och Det svänger om Astrid (2007) uppmärksammar Vivi Edström tre grundläggande inslag som blir viktiga med tanke på den 
miljö-kritiska läsning av Vi på Saltkråkan som föreligger. De handlar dels om naturens stora betydelse i romanen och för Malin i synnerhet, dels den polyfona struktur-en (Edström 2000, 82-85), och slutligen romanens existentiella djup (Edström 2007, 124).

Motiven relaterade till natur- och kultur-miljön flödar över till den grad i Lindgrens roman att detär skäl att tala om ett helt miljötema. Inledningsvis hittar vi författaren Melker, konstruerad litet som ett romantiskt geni. Författarskapet auktoriseras på sätt och vis genom hans osannolika klumpighet och får sin belöning till slut genom det stora författarstipendium han beviljas och som, märkväl, räddar den fysiska platsen med den sociala gemenskap den erbjuder honom och barnen. Opraktiske Melker är mannen som utvalts att visa solidaritet med platsen och dess befolkning. Idéhistoriskt är detta en organistisk

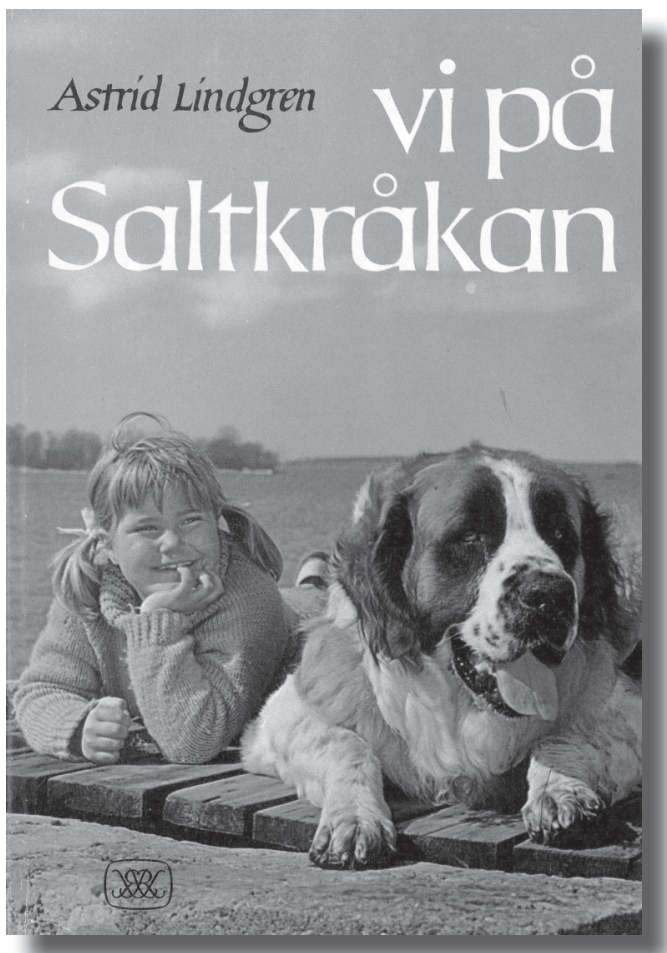

Omslag till Astrid Lindgrens Vi på Saltkråkan, Stockholm, Rabén \& Sjögren, 1964 idé och i enlighet med den brittiske ekokritikern Jonathan Bates inflytelserika tes om en protoekologisk hållning som gjorde sig gällande under romantiken (Bate 1991, 10), kommer man gärna att tänka på de engelska romantikerna och deras besjungande av platsen. Melker besjunger också sin plats, om än i en annan tonart. Han kan som bekant vara mycket högstämd, vilket gör hans klumpighet så mycket mera effektfull och komisk.

Polyfonin i Vi på Saltkråkan är synnerligen betydelsefull för en miljökritisk läsning, eftersom den på ett rätt iögonenfallande sätt bär med sig spektret av miljöfilosofiska positioner. Här kan man finna hela skalan, alltifrån Vestermans arroganta antropocentrism över Södermans pragmatiska och familjen Grankvists utpräglat sociocentriska hållning med inslag av ekocentriska tänkesätt, och vidare över Melkers delvis romantiska, delvis existentialistiska förhållningssätt till vad jag föreslår som Malins milt ekofeministiska perspektiv samt slutligen Pelles levda biocentriska hållning. I anslutning till dessa ingår också det spännande och mycket nyanserade zookritiska motivet som vore värt en alldeles egen artikel. 
Iekokritiskt tänkande framstår idyllen liksom pastoralen som särskilt snävt antropocentrisk i det att den förmedlar en statisk objektssyn på naturen (jfr. Buell 2005,144-45). I den klassiska idyllen är naturen aldrig farofylld. Detta är intressant uttryckligen ur ett miljökritiskt perspektiv, eftersom idyllen i Vi på Saltkråkan på intet sätt är uppenbar eller renodlad, utan hotas genom ett antal faror som får romanen att kommunicera både en fördjupad känsla av samhörighet med och respekt för platsen och den gemenskap den erbjuder. I $V i$ på Saltkråkan destabiliseras följaktligen idyllens antropocentriska perspektiv effektivt genom det välkända lindgrenska mönstret som för in olika slag av faror och hot i berättelsen. Men Lindgren går alltså djupare än så, vilket kommer att diskuteras längre fram genom kontraktets metafor. På olika plan i romanen ingås nämligen och förhandlas det en hel del om kontrakt och, som här föreslås, kontrakt för vilka väderförhållandena ofta utgör själva de grundläggande villkoren. Före det kräver emellertid Malins speciella relation till Saltkråkan en kommentar. Också den relationen bär nämligen drag av överenskommelse.

\section{Den goda klippan}

De naturlyriska inslagen i Vi på Saltkråkan är många och starka, men naturmiljön i romanen utgör långt ifrån enbart något tjusigt sceneri. I stället samverkar den med karaktärerna, bland annat kommer den till tals genom Malin och hennes dagbok. Malin adresserar nämligen Saltkråkan direkt, både i ord och handling. Då Malin första gången anländer till Saltkråkan, upprättar hon omedelbart ett slags partnerskap med ön och glömmer genast den unge mannen Krister hon träffat ombord på båten till Saltkråkan:

[...] Malin skrev inte ett ord om Krister [...] i sin dagbok. Han hoppade av vid sin brygga utan att lämna några spår i hennes sinne. Och bara en kvart senare hade Malin ett mycket mer uppskakande möte som kom henne att glömma allt annat. Det var när båten stävade in mot nästa brygga och hon för första gången såg Saltkråkan (Lindgren, 2004, 16-17).

Visst är det möjligt att hos Malin tala om en projektion av känslor - kärlek, saknad, förlust - på en yttre miljö. Men samtidigt är förhållandet mellan Malin och Saltkråkan inte enbart lyriskt utan också fysiskt intimt. Vivi Edström påpekar att det finns ett samband mellan utvecklingen av Malins kärleksliv och det naturlyriska 
temat (Edström 2000, 83). Det är en viktig iakttagelse, men inom ramen för en eko- och miljökritisk läsning vill jag ändå föreslå att Lindgren går ett steg längre. Hon nuddar vid vad den amerikanska ekokritikern Gretchen Legler i sin läsning av naturberättaren Gretel Ehrlich karakteriserar som en postmodern pastoral (Legler 2007, 22), där Ehrlichs narrativa subjekt ingår ett slags erotiskt, eller i alla fall mycket fysiskt, förhållande med bergen, träden, vattnet, och till och med luften (Legler 2007, 26). I följande citat, där Malin önskar bort sin uppvaktande kavaljer, Krister från båten, blandas det lyriska och det fysiska och klippan under Malin ter sig närapå som hennes älskare:

Solen och vattnet och de lena sommarvindarna, den goda varma hårda klippan som hon låg på, blomdoften som kom svepande inne från grönskan bakom henne och som blandade sig med dofterna från havet, å, alla dessa små välsignade gröna holmar med sina nakna grå strandklippor, sina blommor och sina sjöfåglar, hur kunde man bättre föröda en dag och ett liv än på en av dem? (Lindgren 2003, 133).

Intressant nog bär mannen Malin senare faller för och gifter sig med namnet Petter (från grekiskans petrus, klippa). Hon kommer alltså att ingå ett kontrakt med Petter. Den irriterande Krister framstår däremot som efemär miljöbov i sin snabba motorbåt där han kommer och går (jfr. Edström 2007, 31). Själva mobiliteten blir något suspekt och vittnar om att Krister saknar fysiskt förpliktande anknytning till platsen. Han har inte heller någon avsikt att knyta an; Kristers förhållande till skärgårdsnaturen och det lilla samhället på Saltkråkan bygger enbart på egoistisk lustutlevelse. Här föreslår jag alltså att citatet ovan förebådar ankomsten av Petter i Malins liv och att äktenskapet med Petter innebär ett slags uppfyllande av det kontrakt Malin ingått med Saltkråkan vid första anblicken av ön.

Som zoolog har Petter såväl ett kärleksfullt som vaket intresse för naturmiljön i skärgården. Detta är i och för sig inte särskilt märkligt, desto intressantare blir det däremot mot bakgrund av en betydande ekokritisk utvecklingslinje. I sitt berömda men omstridda verk The death of nature (1980) skildrar den ekofeministiska idéhistorikern och vetenskapsfilosofen Carolyn Merchant hur utvecklingen av den moderna naturvetenskapen löpt parallellt med hård exploatering och kontroll av såväl naturen som av kvinnorna allt sedan den vetenskapliga revolutionen och renässansen. Enligt Merchant har den manliga civilisationens program handlat om utforskandet av naturen och det kvinnliga i syfte att upprätta dominans och hierarki. 
Ur detta ekokritiska perspektiv kan man tänka sig att zoologen Petters utplacerande av radiosändare på sälarna och hans intresse för Malin blir något dubiöst. En sådan läsart skulle emellertid bli alltför grovmaskig, för att inte säga absurd: Petter skulle framstå som en ondskefull personifikation av en idé och dess tillämpning. Lindgren gör fullständigt klart för läsaren att den vänlige och omtänksamme Petter inte har några suspekta maktmotiv och att hans kärlek till naturen är lika genuin och djup som Malins egen. Med hänvisning till Legler vågar jag påstå att Lindgren finner en egen väg här, som inte är dikotomisk men ändå modern. I viss mån liknar Lindgrens hantering av motivkretsen kring naturen och vetenskapen i $V i$ p̊̊ Saltkråkan Rachel Carsons i hennes epokgörande och genremässigt självklart fundamentalt annorlunda verk Silent Spring (1962), där kärleken till naturen är uppenbar, medan naturvetenskapen kan utgöra både problem och lösning. Däremot blir naturvetaren Petter en av de goda krafterna i romanen med ett seriöst och förpliktande intresse för skärgårdsnaturen. Denna seriositet ställs mot det distanserade och objektiverande synsätt som först Krister och sedan direktör Karlberg representerar och som både möjliggör och förstärks av en flyktig relation till Saltkråkan.

I Vi på Saltkråkan har Astrid Lindgren följaktligen placerat problemet med naturens död, om man så vill, på en annan, inte primärt $e k o-$ utan uttryckligen miljökritisk nivå. Hon presenterar en nyanserad bild av platsen med den gemenskap som ön Saltkråkan hyser, det vill säga den integrerade kommunitet hon låter bestå av både människor och djur i relation till naturlandskap och bebyggelse. Det skulle föra fel om man sade att hotet enbart kommer utifrån, för det kommer också inifrån. Naturfenomenen det växlande vädret, på och kring ön Saltkråkan, utgör potentiella hot mot befolkningen som en del av miljön, liksom Vesterman och hans utpräglat utilistiska attityd till sälarna utgör ett hot mot djurlivet som del av samma miljö. Att med Merchant och Buell däremot identifiera ett särskilt instrumentellt, exploaterande och dominerande synsätt på miljön för oss till problemets kärna: det är en viss syn på naturen, skärgårdsmiljön, och på platsen, som förnekar dess känslomässiga och sociala betydelse, som innebär det största miljöhotet i romanen. Det är den miljösynen som hotar störta familjen Melkerson från platsen ytterst $\mathrm{i}$ havet ner i havet. Men genom den gemenskap Melkersons och ortsborna byggt upp, genom den specifika platstillhörighet de förverkligat, går de slutligen trygga. Denna platstillhörighet förverkligas i romanen långt $\mathrm{i}$ kontext av väderförhållandena. 


\section{Kontraktet: vädret, platsen och miljörättvisan}

Det är viktigt notera att väderfenomen som tjock dimma, störtregn, kraftiga åskväder, snöstormar, hård köld och starka vindar alltid utgör faror, även om vi i den moderna, urbaniserade världen inte på länge varit vana vid att förstå dem på det sättet. Men Astrid Lindgren har aldrig glömt det: i Vi på Saltkråkan, men också t.ex. i Bullerbyn och Madicken, visar hon varför och hur extrema väderförhållanden är farliga. I synnerhet i Vi på Saltkråkan utgör väderfenomenen inte enbart en spännande bakgrund till karaktärernas handlingar utan naturkrafter man måste räkna med och respektera. Hit hör också en skärande medvetenhet om den sårbarhet som själva existensen för med sig, framhävd både genom den sorgliga undertonen i romanen och genom en inkännande exposition av de faror just den här specifika naturmiljön "ytterst i havet" innebär. Här kommer den eskatologiska aspekten in; de yttersta tingen i existentiellt hänseende, d.v.s. frågorna om livet och döden, är aldrig långt borta från de yttersta platserna i geografisk bemärkelse.

Ömsesidigheten i relationerna mellan familjen Melkerson och ortsborna skrivs in genom vädret och dess förhållande till det geografiska läget längst ut i havsbandet. Här aktualiseras ånyo metaforen kontrakt, ett kontrakt för vars uppfyllande vädret i hög grad utgör garant. Kontraktsmetaforen fungerar intrikat hos Lindgren; den får såväl en enkel och uppenbar som en mer komplex sida. Det uppenbara handlar om ägarförhållanden och hyresgäster. Man hyr och hyr ut, spekulerar, köper och säljer. Det som är viktigare och gör metaforen verkningsfull, är att man avreser och återvänder, delar farofyllda situationer, och överraskande växlar perspektiv på vädret och naturmiljön ortsbor och sommargäster emellan. Det intressanta är den långt genomförda ömsesidigheten i kontraktsskrivandet. Melkersons väljer inte bort Saltkråkan och Snickargården trots ösregn, kyla och långtgången väta inomhus då de anländer dit första gången. Pelle kan inte sova på grund av de skrämmande åskvädren och familjen återkommer mitt i kallaste vintern, då ingen turist skulle sätta sin fot på ön. Familjen Melkerson tar därmed tydligt ställning inte bara till utan för platsen genom att på ett antal sätt bekräfta att man tillhör den.

Kontraktet fungerar också åt andra hållet, i riktning från ortsborna mot familjen Melkerson. Driftiga skärgårdsbarnet Tjorven, överlevaren under alla omständigheter, riskerar förfrysning och räddas in i Snickargårdens värme av Malin, där hon liten och ynklig bäddas ner. Den tjocka och farofyllda dimman drabbar båda 


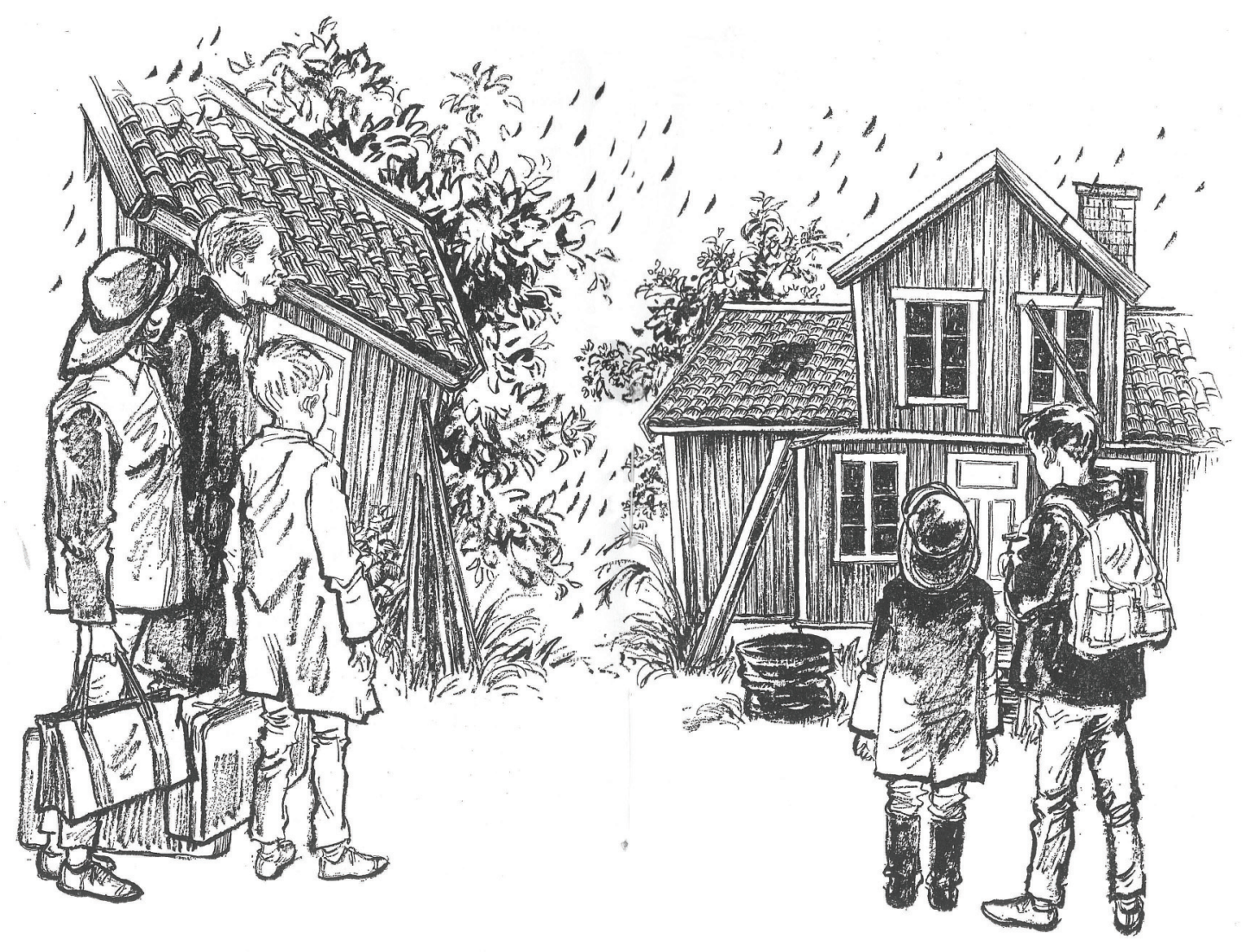

Familjen Melkerson anländer till Snickargården på Saltkråkan. Illustration av Ilon Wikland ur Vi på Saltkråkan av Astrid Lindgren. Stockholm: Rabén \& Sjögren, 1964

familjernas barn. Det visar sig att tuffa Tjorven är rädd för åskan så till den grad att hon försätter sig och Pelle i fara genom att tappa årorna, medan Pelle, tack vare Tjorvens pappa Nisse Grankvists positiva inflytande på stadsbarnet, inte tycker åskan är obehaglig ens då han - farligt nog - är ute på sjön i ovädret med Tjorven efter att ha hämtat en kanin. I det första citatet nedan understryks också det eskatologiska elementet, gränsande till det apokalyptiska, genom kopplingen av åska, domedag och den i romanen ständigt återkommande, ultimata rumsangivelsen "ytterst i havet". 
En hel natt satt Melkersons i Snickargårdens kök och såg blixtarna fara ner i sjön och fjärden lysas upp som på ljusa dagen. Med dova, förskräckliga knallar rullade åskan fram över öarna ytterst i havet, det lät som domedagen, och vem tordes sova då? [...] Det var ingen ordning alls om nätterna här på Saltkråkan. Det gick väl an att vara vaken för att det var kalas eller midsommarafton men åskväder en hel lång natt, det var påfrestande, tyckte Pelle. Fast Nisse Grankvist hade förklarat för honom att alla väder var vackra väder, och Pelle trodde blint på farbror Nisse. (Lindgren, 2004, 119-20).

Tjorven tittade sakkunnigt på molnen som tornade upp sig på himlen bakom Lillasken, och hon sa dystert:

'Det blir åska!'

Ja, nog var det bra att hon inte skulle ro så långt. Visserligen var hon tapper som en härförare, men där fanns en svag punkt hos henne. Hon var åskrädd, fastän hon hade svårt att medge det. (Lindgren, 2004, 170-71).

Varför är det då uttryckligen genom vädret som de avgörande villkoren ställs för uppfyllande av kontraktet? Därför att klimat och väderförhållanden, som längst ut i skärgården ofta kan vara mycket svåra och som varje skärgårdsbo därför måste beakta, förhålla sig till och respektera, samtidigt markerar var gränsen för det yttersta, ultimata löper. Ingen besegrar vädret. Men har man accepterat att leva med de växlande väderförhållandena och de faror de medför, har man också visat sin vilja till samhörighet med platsen. En boning ytterst i havet förpliktar. Och det är på denna punkt som Lindgren på ett enastående vis vänder kontraktsmetaforen med vädret som byggsten upp och ner genom att ställa frågan: Vad allt kan då inte vackert väder medföra? Vad uppenbaras i det strålande solskenet och ute på det spegelblanka havet? En ytlig typ som Krister i snabbgående motorbåt, som vi sett. Men också en direktör Karlberg på jakt efter värdefull tomtmark.

Här bör man alltså fråga sig hur kontraktsmetaforen fungerar i kontext av Karlbergs uppdykande mot slutet av romanen. Det är betecknande att Karlberg och hans dotter Lotta anländer en sommardag i stiltje och strålande solsken. Ytplanet i bilden förstärks - Karlberg är mäktig spekulant, nu handlar det enbart om affärer - medan djupplanet töms; här bäddas minsann inte för gemenskap och goda grannrelationer. Karlberg omges således av ett överflöd av pengar och en myckenhet vackert väder. Intressant nog för det vackra vädret alltså med sig dåliga nyheter för familjen Melkerson. 
Medan elementens raseri verkar bidra till att förstärka den inbördes känslan av trygghet och gemenskap i romanen och bidra till sammanhållningen av platsen hur utsatta för vädrets makter ortsbor och familjemedlemmar än kan känna sig, slås tryggheten sönder i det vackra vädret. Vackert väder kopplas direkt samman med hotet mot Melkersons gemenskap med ortsborna och familjens vid det här laget, som det ter sig för dem och deras grannar, självklara tillhörighet till platsen. Visserligen är tillvaron på Saltkråkan ofta solig i de flesta avseenden, men väderväxlingarna är legio och det är aldrig någonsin vid storm, dimma eller köld som ortsborna och familjen Melkerson förlorar hoppet fullständigt. Detta sker bara i den bländande, alldeles vindstilla solskensdagen.

Att det är något misstänkt med den vackra dagen, signaleras tydligt tre sidor före Karlbergs uppdykande:

Vad kunde man inte vänta sig av en dag som började med en pojkes lyckliga skratt och med ett så välsignat vackert väder? Den senaste veckan hade varit odräglig, bara blåst och regn och kyla, och så plötsligt en så här underbar morgon - Malin beslöt att duka frukosten ute på tomten.

Hennes far var vaken och höll på att klä sig inne i kökskammaren. Han sjöng medan han gjorde det.

"Det är måndag morron...och jag känner mej så gla-aad..."

"Du ska inte sjunga på fastande mage", ropade Malin till honom. "Då får du gråta innan kvällen, vet du inte det?" (Lindgren, 2004, 315).

Malins misstanke visar sig givetvis befogad. Snart står det klart att direktör Karlberg vill äga deras tomt, riva deras hus och bygga något nytt och modernt istället. Detta understryker att Karlberg förhåller sig varken respektfullt eller seriöst till platsen och dess inbördes relationer mellan människor, djur och natur. En "boning ytterst i havet", med allt vad den satsen innebär av tillit, hot och ödmjukhet är han nog inte intresserad av; han vill ha en lyxbostad och en vacker solnedgång som bakgrund. Karlberg saknar inte bara skärgårdskunskap, vilket står klart då Tjorven förtöjer hans båt och han omtalar knopen som knut. Till skillnad från Melkersons har han heller ingen brist på pengar och läsaren kan förmoda att denne direktör Karlberg knappast skulle uthärda väderväxlingarna "ytterst i havet". Karlberg vill köpa sig en tjusig utsikt. Budskapet han förmedlar är att inget är värt så mycket att det inte kan köpas.

De mycket olika attityderna till skärgårdsmiljön står klara: i kraft av sin ekonomiska makt kan Karlberg inta ett instrumentellt 
och objektiverande förhållningssätt till miljön; för honom handlar det följaktligen om att äga ett vackert landskap. För Melkersons och öborna är den fysiska miljön - husen, naturlandskapet och djuren inräknade - fyllda med mening, levande gemenskap och förknippade med existentiell kamp. Inom ramen för en miljökritisk läsning bör detta förstås inte enbart som en traditionell klassproblematik utan bör läsas också genom idén om miljörättvisa (se t.ex. Adamson, Evans, and Stein 2002, 4; jfr. Allen 1999, 191-92), en miljöetisk tanke som delvis anknyter till kontraktets metafor i romanen. Miljörättvisa handlar om alla människors lika rätt till en trygg boende- och livsmiljö, det vill säga en miljö som inte är så förstörd och nedsmutsad att den blir direkt förödande för mänskligt liv. I det sammanhanget är förhållandet mellan ekonomisk makt och maktlöshet centralt; de förstörda miljöerna är framför allt de fattigas, men till exempel i USA också i viss mån medelklassens miljöer. Miljörättvisa i globalt perspektiv har aldrig kunnat och kommer aldrig att kunna uppfyllas till följd av den långtgångna industriella exploateringen av miljön. I fallet Saltkråkan handlar det självfallet inte om någon miljöförstöring (i bemärkelsen nedsmutsning), men nog om ett miljöhot kopplat till missbruk av ekonomisk makt: om den för många människor så förödande makt som hotar förstöra och beröva dem den fysiska och sociala miljö som utgör deras hem och gemenskap. Också för detta blir alltså kontraktsmetaforen, där vädret - i detta fall det så kallade vackra vädret - utgör grundstenen, betydelsefull.

\section{Om de yttersta tingen}

Romanen får sin upplösning först i sista kapitlet eller snarare, vilket läsaren anar, redani rubriken för kapitlet som lyder" En boningytterst i havet". I ljuset av den i romanen återkommande platsangivelsen med biblisk klang tillsammans med den i texten föga explicit men ändå kännbart närvarande saknaden efter fru Melkerson, menar jag att romanen kan läsas i liknande termer; att familjen Melkerson slutligen vederfars en stor godhet, ja, rentav en stor nåd. Och ställda inför det ultimata hotet, inför de yttersta tingen, d.v.s. förlusten av vad som efter fru Melkersons bortgång är det viktigaste i deras liv, undanröjs hotet slutgiltigt först efter många traumatiska turer av suspens.

I sista minuten får farbror Melker ett stort författarstipendium som skulle räcka till för att köpa Snickargården, men ska han hinna till Norrtälje och fastighetsförmedlare Mattsson i tid innan denne undertecknar kontraktet med direktör Karlberg? Nej, han 
hinner inte, men vägrar acceptera faktum och anstränger sig att rädda Snickargården som om han faktiskt kämpade för sitt liv. Och räddningen kommer, men genom skärgårdsbarnet Tjorvens hand och med hjälp av den pålitliga och kärleksfulla gemenskap hon ingår i (hon är givetvis bekant med ägaren till Snickargården, fru Sjöström) , där platsens och inte penningens värderingar råder.

I Vi på Saltkråkan inträffar således aldrig något kontraktsbrott. Kontraktet som ingåtts mellan Melkersons och ortsborna och, som en utlöpare av de senare, ägaren till Snickargården, fru Sjöström, står fast. Melkers synnerligen lägliga författarstipendium innebär en avgörande omständighet, men skipandet av rättvisa blir ytterst beroende av Tjorvens "härföraregenskaper". Upplösningen förebådasi det skede då Karlberg uppmanar Tjorven att hjälpa honom angöra bryggan och han inte behärskar skärgårdsvokabulären, vilket Tjorven nogsamt noterar. Också djuren fungerar förebådande och en platsens motmakt mot Karlberg och hans värld och värderingar etableras därmed på djurens och barnens nivå. Båtsman är givetvis en hund skapad för att klara sig i en hård miljö medan det framgår att Lottas överciviliserade pudel Musse bara är en stor bluff. Också hundarnas namn talar om skillnaden i attityd: Musse signalerar ett disneyfierat förhållningssätt och bejakandet av en fantasinatur som inget har att göra med miljön på Saltkråkan att göra, medan namnet Båtsman bekräftar skärgårdslivet $\mathrm{i}$ alla dess varianter. Budskapet blir att livet här ute är tufft och varken disneyhundar, rika direktörer eller lyxvillor hör hemma här. De tre kronor som Tjorven ironiskt nog tjänar på Karlberg och ger till Pelle som tröst, kommer att utgöra den handpenning som gör det möjligt för Pelle att underteckna köpebrevet hos fru Sjöström. Dessa fattiga slantar utgör med andra ord en mycket dyrbar symbol i romanen genom vilken parterna, familjen Melkerson och ortsborna, förs tätare samman i platsens namn. Platsen är därmed räddad. Inte som idyll utan som existentiell grundkategori: som en boning ytterst i havet.

\section{Slutsatser}

Att söka det ultimata, det yttersta, innebär att sätta kurs mot den gräns där inga garantier ges och de som finns riskerar ge vika. Det innebär att acceptera förlust och den sårbarhet existensen för med sig. Kärnan i en miljökritisk läsning utgörs av insikten om att vår utsatthet som levande varelser beror på att vi är situerade i rummet och tiden, vår existens är i allt väsentligt bunden till fysiska platser 
och beroende av fysiska miljöer som gör oss sårbara - uttryckligen till följd av detta beroende (Buell 2001, 55). I insikten om utsatthet ingår också vetskapen om att platsbegreppet hyser såväl samvaron och samspelet med människor och andra levande varelser som själva beroendet av den fysiska lokalen. Handlingen i Vi på Saltkråkan har ett tragiskt men bärande element; det jag här kallat en eskatologisk underström. Plötsligt kan en mamma dö, nära och kära försvinna på havet, åskan slå ned och ett hem gå förlorat. Malins intima förhållande till naturmiljön utgör på sätt och vis en grundsten för det fortsatta förloppet, en synekdoke för den samhörighet med platsen och dess befolkning som hela familjen Melkerson lyckas skapa tillsammans med ortsborna själva. Ändå innebär allt detta en farofylld kamp; det ären balansgång över avgrunden. Melkersons kämpar försin"boning ytterst i havet" i moderns slutgiltiga frånvaro. För läsaren står det klar att detta är ett ohyggligt riskfyllt projekt. I det sammanhanget blir tanken om kampen för miljörättvisa aktuell. I fallet Vi på Saltkråkan handlar det självklart aldrig om miljöförstöring i snävaste bemärkelse, men nog om pengar, makt och exploatering av den miljö som för ortsborna och familjen Melkerson är deras hem. Mycket av handlingen i Vi på Saltkråkan utspelar sig vid en "yttersta gräns". Vad kan då detta tänkas innebära i vår tid, katastrofrapporternas 2010-tal? Undergångsstämningarna i massmedierna dränker oss nästan i sin apokalyptiska jättevåg. Vi påminns dagligen genom deras rapportering på ett nästan våldsamt sätt om att den fysiska miljön, såväl naturmiljön som den byggda miljön, utgör den yttersta gränsen för allt mänskligt liv. Vi på Saltkråkan i sin tur bekräftar att beroendet av den fysiska miljön, och därmed beroendet av andra människor, bör erkännas som ofrånkomligt och självklart riskabelt men ändå som något man både kan och bör förhålla sig till med tillit. Med Vi på Saltkråkan skapade Astrid Lindgren en tidig och i många avseenden hållbar miljöfiktion (Ahlbäck, forthc.), som vi hoppfullt kan vända oss till också i tider som denna, präglad av undergångens förödande retorik.

Biographical information: Pia Maria Ahlbäck is lecturer at the department of English language and literature at Åbo Akademi University. Her dissertation on George Orwell and twentieth century environmental thought (2001) was one of the first in the field of eco- and environmental criticism in Scandinavia. Her current projects involve a study of twenty-first century climate fictions in literature and film. Contact:pia.ahlback@abo.fi 


\section{Bibliografi}

Adamson, Joni, Mei Mei Evans and Rachel Stein (eds.). The environmental justice reader: politics, poetics and pedagogy. Tucson: University of Arizona press, 2002.

Ahlbäck, Pia Maria. (Forthc.) "Naturlyrik, klimatfiktion, ekokritik. Miljön i litteraturen och litteraturvetenskapen runt år 2010". Artikel baserad på föredrag hållna vid Vetenskapsdagarna, Helsingfors, 7.1. 2009 och Finlandssvenskt kulturseminarium, Mariehamn, mars 2009.

Allen, Barbara L. "Narrating the toxic landscape of Cancer alley, Louisiana". In Nye, David E. (ed.) Technologies of landscape: from reaping to recycling, Amherst: University of Massachusetts Press, 2000, 187-203.

Bate, Jonathan. Romantic ecology: wordsworth and the environmental tradition. London: Routledge, 1991.

Buell, Lawrence. Writing for an endangered world: literature, culture, and environment in the United States and beyond. Cambridge: Mass., Harvard UP, 2001.

Buell, Lawrence. The future of environmental criticism. Oxford: Blackwell, 2005.

Edström, Vivi. Astrid Lindgren: a critical study. Stockholm: Rabén \& Sjögren, 2000. (Originalets titel Vildtoring och lägereld. Stockholm: Rabén \& Sjögren, 1992)

Edström, Vivi. Det svänger om Astrid. Stockholm: Rabén \& Sjögren, 2007.

Heise, Ursula K. Sense of place and sense of planet. New York: Oxford UP 2008.

Legler, Gretchen. "Toward a postmodern pastoral: the erotic landscape in the work of Gretel Ehrlich". I The ISLE reader: ecocriticism, 1993-2003, Michael P. Branch and Scott Slovic, eds., Athens and London: University of Georgia Press, 2003, 22-33.

Lindgren, Astrid. Alla vi barn i Bullerbyn. Stockholm: Rabén \& Sjögren, 1947.

Lindgren, Astrid. Madicken. Stockholm: Rabén \& Sjögren, 1960.

Lindgren, Astrid. Vi på Saltkråkan. Stockholm, Rabén \& Sjögren, 2004, (1964).

Merchant, Carolyn. The death of nature: women, ecology and the scientific revolution. San Fransisco: Harper and Row, 1980. 